\title{
ヘリシティー注入配位型低アスペクト比トカマクの 平衡解析
}

\author{
学生員 小野 亮 (東京大) \\ 正貝桂井誠 (東京大) \\ Analytical Expression of Equilibrium Configuration of Low Aspect Ratio Tokamaks \\ with Helicity Injection \\ Ryo Ono, Student Member, Makoto Katsurai, Member (University of Tokyo)

\begin{abstract}
Plasma current drive is one of critical problems to be solved in the development of fusion reactors under steady operation of low aspect ratio tokamak. DC helicity injection that has been used for the current drive of spheromak plasmas has also been successfully applied to low $A$ tokamak plasmas. In this paper, the analytical expression of the equilibrium configuration has been derived for low $A$ tokamak plasmas with a rectangler cross section. Two types of electrode configurations for the helicity injection, one the coaxial type, and the other the polar type, are considered. The condition of $q$ profiles that provide the reversal magnetic shear are studied.
\end{abstract}

キーワード：低アスペクト比トカマク、ヘリシティー注入、同軸電極配位モデル、内側電極配位モデル、安全係数

\section{1.はじめに}

最近、磁気核融合プラズマ閉じ込め研究において、アス ペクト比 $(A$ 三大半径/小半径) の低いトカマク方式が着目 されている(1,2)。通常のアスペクト比 3 程度のトカマクにお いては、中央部に設置した変流器コイルによってプラズマ 電流の駆動を行っている。しかし、アスペクト比が 1.5 程度 以下の低アスペクト比トカマクにおいては、中心対称軸に 沿っての外部スペースは狭く、トロイダル磁界発生用導体 の周囲には大容量の変流器を設置する余裕がない。よって プラズマ電流の長時間駆動には変流器に代わる別の方法が 検討されねばならない。その一つとして提案されているも のがへリシティー注入法である。

これはもともと、中心対称軸周辺に如何なる構造物も設 置せず、従って中央部に変流器設置がない、スフェロマック 配位を対象にしていた(3)。具体的に最初に実証されたのは 図1(a)に示す同軸型プラズマ銃スフェロマック配位である。 ここでは、内外電極を通してプラズマ内にポロイダル電流 の直流電流 $I_{e}$ を注入する。この注入電流は自分が作るト口 イダル磁界の力でブラズマ内に侵入しようとするが、そこ でMHD 的磁気緩和現象を引き起こし、ポロイダル磁界成 分の発生、すなわちトロイダル成分を有するプラズマ電流 駆動が行われる。

ここで重要な役割を果たす磁気緩和による配位調整機能 は、そもそも 1970 年代に逆磁場ピンチ (RFP)の形成に関
連してJ.B.Taylorによって提唱されたもので(4)、さらにそ の元を巡ると天体プラズマに打けるWoltjer ${ }^{(5)}$ の無力磁場 配位理論に行き着く。この理論では、初期に力学的平衡か ら外れた状態にいる磁化プラズマは、磁気へリシティーを 一定に保って磁気エネルギー最小となる配位へと自動的に 変化することを述べており、その最終状態は、固有值が架 間によらない一定値を有する無力配位 (force free) となるこ とが示されている。今日核融合プラズマ研究分野において この状態は Taylor 状態とも呼ばれている。この理論はその 後、外部電流が出入りしているような場合に拡張され、内 部において電流の抵抗減衰があるような場合においても、 電流注入によってそれが保持されることが指摘されるにい たった。この場合、抵抗によるへリシティー損失を外部電 流によって補うことになり、この方法によるプラズマ電流 の駆動をへリシティー注入法と呼ぶ。

上記同軸プラズマ銃方式では、電極を通しての電流注入 でこのへリシティーが注入されることになる。この方式と 異なる配位として図1(b) に示すフラックスコアー・スフェロ マック(6) (バンピーZピンチ(7) $)$ がある。ここにおいては、 プラズマ容器と中心対称軸が貫通する両極部に電極を設置 してその間に外部電流を注入する。この配位の生成は、す でに実験的に確認されている(8)。

さて、同じ原理が低アスペクト比トカマクの電流駆動に 適用出来ることが最近明らかにされている。具体的な構造 としては上述の図1に対応して図2のようなものが可能であ 
(a)

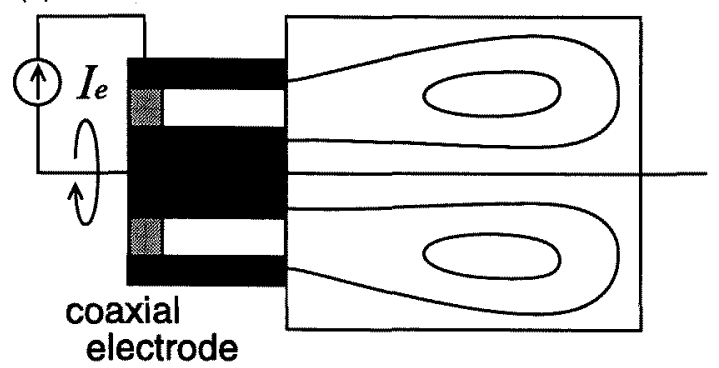

(b)

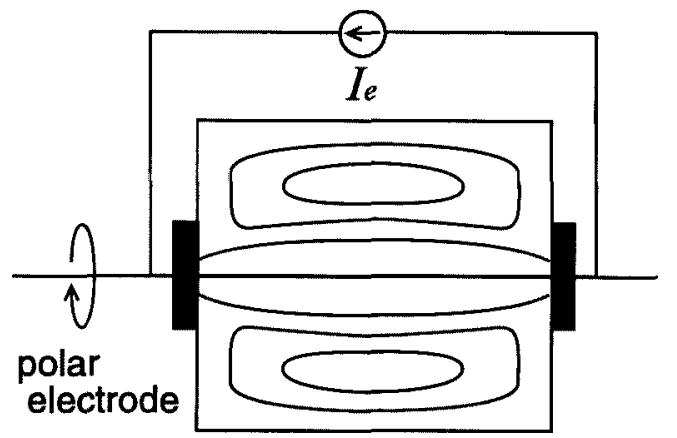

図 1 ヘリシティー注入型スフェロマック。(a) 同 軸電極配位、(b) 両端電極配位。

Fig.1. Helicity injection spheromak. (a) Coaxial electrode type, and (b) polar electrode type.

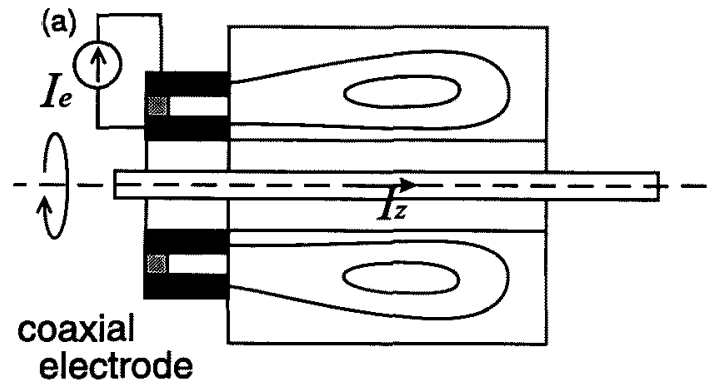

(b)

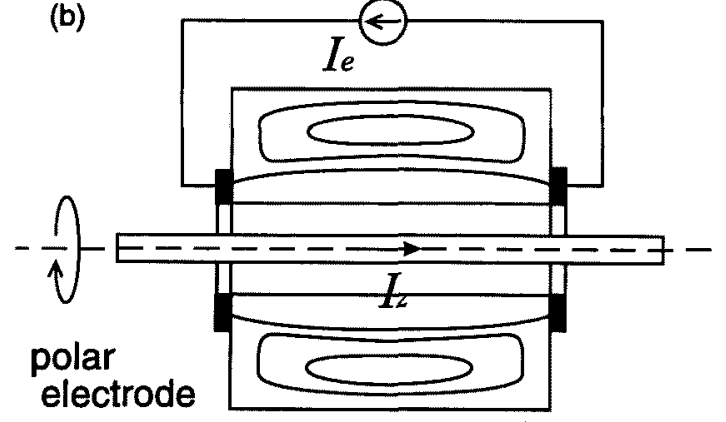

図 2 ヘリシティー注入型(低アスペクト比)卜カ マク。(a) 同軸電極配位、(b) 両端電極配位。

Fig.2. Helicity Injection (low aspect ratio) tokamak. (a) Coaxial electrode type, and (b) polar electrode type.
る。図1との違いはプラズマ容器がトーラス形状となって中 心対称軸に沿ってトロイダル磁界発生用導体が設置さてお り、トロイダル磁界発生電流 $I_{z}$ が流れるようになっている 点である。最初にワシントン大学の HIT 装置 (HIT: Helicity Injection Tokamak)によって、図 2(a) の構造のもとで実験 的研究が行われ、配位生成・維持についての原理検証が行 われている(9)。このようにへリシティー注入は電流駆動に 有用である他に、安全係数 $q$ の分布の制御が可能となって、 エネルギー閉じ込め特性への好影響という期待もあり、次 世代のメガアンペア装置への適用が検討されている。

本論文に拝いては以上のような背景のもとで、図 2をモ デル化した図3の諸構造を対象にして、今後の理論的検討 の出発点となる平衡配位の解析解を求める。解の求めやす さの点から、いずれにおいても矩形断面を仮定して、電極 は図2とは異なって側面に配置されているものとした。図 3(b-2)のモデルは解析法が (b-1) と同じであるため、今回 は計算を省略する。以下では、2 章においては同軸電極配 位タイプ (HIT タイプ)の平衡解を、3章においては内側電 極配位タイプ(フラックスコアー・スフェロマック配位タイ プ)の平衡解を示す。4 章に打いては解析をもとにフラック スプロットと安全係数 qの分布を示し、特にトカマクにおい て最近注目されている、径方向に対して $q$ 分布が負の勾配 を持つ領域(10)を探求する。5 章に扔いては結言を述べ。

\section{2. 同軸電極配位の平衡解析}

〈2・1 同軸電極配位モデル 基本式は無力磁界配位 に対するグラッド・シャフラノフ方程式である(11)。朝対称 トーラスに扔てて、磁気面 $\Phi$ とロイダル磁界 $B_{\varphi}$ の間に

$$
B_{\varphi}=\frac{\kappa \Phi(r, z)}{r} \quad(\kappa>0: \text { const })
$$

の関係を仮定すると、無力磁界配位 $(\nabla \times B=\kappa B: \kappa$ は望 間によらない固有值) が導ける。このとき、グラッド・シャ フラノフ方程式は次式のようになる。

$$
r \frac{\partial}{\partial r}\left(\frac{1}{r} \frac{\partial \Phi}{\partial r}\right)+\frac{\partial^{2} \Phi}{\partial z^{2}}+\kappa^{2} \Phi=0
$$

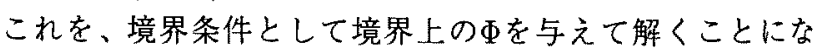
る。座標系としては $(r, z)$ の円柱座標を考え $z$ 軸を中心対称 軸とし、プラズマは長さ $L$ 、内半径 $b$ 、外半径 $R$ の矩形断面 を有するものとする。ここで $z$ 軸に沿って外部トロイダル 磁界発生のための電流 $I_{z}$ を流し、それにより (2) 式で計算 される内電極 $r=b$ 上での $\Phi を \Phi_{0}$ とする。

図 4のように内外電極 $E_{1}, E_{2}$ とし、その $z$ 方向の幅を $L_{e}$ とする。この同軸ガンによるヘリシティー注入を模擬した モデルを考え、平衡解を(2) 式を解くことにより導きだす。 図 4のモデルに関して (2) 式を変数分離し一般解を求める と、次式のような関数形が求まる。

$$
\begin{aligned}
\Phi(r, z)= & r\left\{a_{J} J_{1}(\nu r)+a_{N} N_{1}(\nu r)\right\} \sin \mu z \\
& +b_{0} \sin \kappa z+b_{1} \cos \kappa z
\end{aligned}
$$

ここで、 $a_{J}, a_{N}, \mu, b_{0}, b_{1}$ は定数であり、 $J_{1}, N_{1}$ はそれぞれ 1 次の第 1 種ベッセル関数、ノイマン (第 2 種ベッセル) 関 


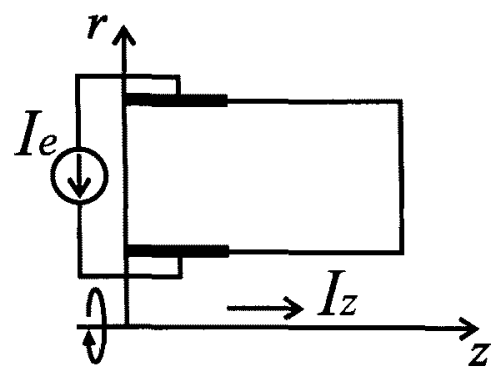

(a)

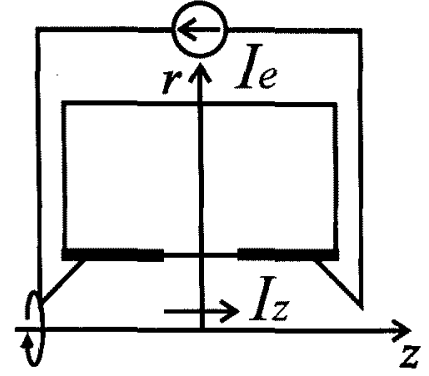

(b-1)

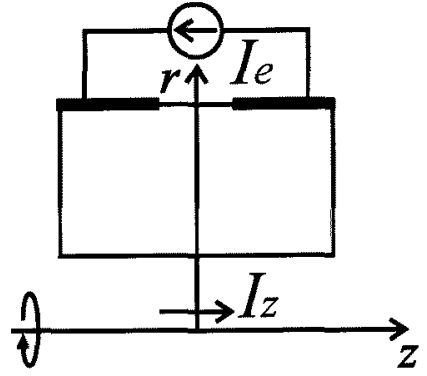

(b-2)

図 3 (a) 同軸電極配位 (HIT タイプ)、(b-1) 内側電極配位 (内周形)、(b-2) 外側電極配位 (外周形)。

Fig.3. (a) Coaxial electrode type, (b-1) polar electrode type (inner circuit type), and (b-2) polar electrode type (outer circuit type).

数を表し、 $\nu$ は次のような值である。

$$
\begin{cases}(\kappa \geq \mu \text { のとき }) & \nu=\sqrt{\kappa^{2}-\mu^{2}} \\ (\kappa<\mu \text { のとき }) & \nu=\sqrt{\mu^{2}-\kappa^{2}}\end{cases}
$$

また $\kappa く \mu に お い て 、 J_{1}, N_{1}$ はそれぞれ変形ベッセル関数 $I_{1}$, $K_{1}$ に置き換える。

図 4 の長さ $L_{e}$ の西電極 (太線部分) を通して外部電流 $I_{e}$ を

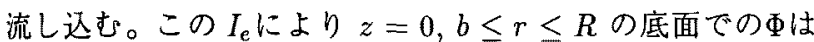
$\Phi_{1}$ となるものとし、電極に沿っての $\Phi$ の変化は図 4 のように 正弦波で与えられるものとする。すなわち、この $\Phi_{0} か ら \Phi_{1}$ の変化は通常直線で近似するが、ここでは滑らかに $\Phi_{0}, \Phi_{1}$ とつながるよう正弦波変化を仮定した。これは、この解を もとに将来数值計算等を進めるとき、Фの微分に際して不 連続点が現れないように考慮したためである。以上の考察 をもとにすると、境界条件は

$$
\begin{cases}\Phi=\Phi_{0} & (z=L) \text { or }\left(r=b, R \text { and } L_{e}<z<L\right) \\ \Phi=\Phi_{1} & (z=0)\end{cases}
$$

と与えられ、電極部分は図4のように正弦波で近似する。し たがって、 $r=b, R の$ 境界上の $\Phi$ を $\Phi_{W}(z)$ とすると、(5) 式 を考慮すれば $\Phi_{W}(z)$ は次式のように求められる。

$$
\begin{array}{r}
\Phi_{W}(z)= \begin{cases}\frac{\Phi_{e}}{2} \cos k_{e} z+\frac{\Phi_{0}+\Phi_{1}}{2} & \left(0 \leq z \leq L_{e}\right) \\
\Phi_{0} & \left(L_{e}<z \leq L\right)\end{cases} \\
\text { たたし } \Phi_{e}=\Phi_{1}-\Phi_{0}, \quad k_{e}=\pi / L_{e}
\end{array}
$$

$z=0, L$ の境界に注目すると、Фはrによらず一定值をと るので (3) 式の右辺第 1 項は消える。したがって

$$
\left\{\begin{array}{l}
\sin \mu L=0 \quad \rightarrow \mu=\mu_{i} \equiv \frac{\pi}{L} i \quad(i=0,1,2, \cdots) \\
\Phi(r, 0)=\Phi_{1} \quad \rightarrow b_{1}=\Phi_{1} \\
\Phi(r, L)=\Phi_{0} \quad \rightarrow b_{0}=\frac{\Phi_{0}-\Phi_{1} \cos \kappa L}{\sin \kappa L}
\end{array}\right.
$$

これより、体不連続值 $\mu_{i}$ とることがわがり、(3) 式の右 辺は各 $\mu_{i}$ の代数和となる。すなわち

$$
\begin{gathered}
\Phi(r, z)=\sum_{i} r F_{i}(r) \sin \mu_{i} z+b_{0} \sin \kappa z+\Phi_{1} \cos \kappa z \\
\text { ただし } F_{i}(r)=\left\{a_{J i} J_{1}\left(\nu_{i} r\right)+a_{N i} N_{1}\left(\nu_{i} r\right)\right\}
\end{gathered}
$$

ここで、 $\kappa=\mu_{i}$ とすると $b_{0}$ が発散するので、 $\kappa \neq \mu_{i}$ とする。

$\langle\mathbf{2} \cdot \mathbf{2}\rangle a_{J i}, a_{N i}$ の計算 $\quad r=R$ のとき $\Phi(R, z)=\Phi_{W}(z)$ なので、次式が成立する。
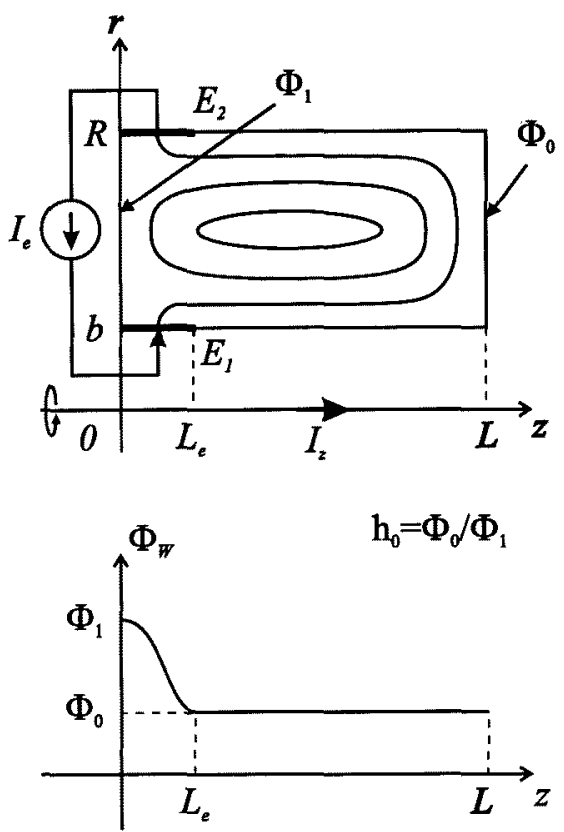

図 4 同軸電極配位モデルと $r=b, R て ゙ の$ 境界条件。

Fig.4. HIT model and boundary condition at $r=b, R$.

$$
\Phi_{W}(z)=\sum_{i} R F_{i}(R) \sin \mu_{i} z+b_{0} \sin \kappa z+\Phi_{1} \cos \kappa z
$$

(9) 式の両辺に $\sin \mu_{j} z$ を外て $z: 0 \rightarrow L$ で積分すると、

(6)式を用いて左辺、右辺ともに計算でき、次式を得る。

$$
\begin{array}{r}
-\frac{\Phi_{1}+\Phi_{0}}{2 \mu_{j}}\left(\cos \mu_{j} L_{e}-1\right)- \\
-\frac{\Phi_{0}}{\mu_{j}}\left(\cos \mu_{j} L-\cos \mu_{j} L_{e}\right)+C_{2} \\
=\frac{R L}{2} F_{j}(R)+\frac{\mu_{j}}{\kappa^{2}-\mu_{j}^{2}} \Phi_{a} \quad(10)
\end{array}
$$

ただ

$$
\begin{aligned}
& C_{2}=\frac{\Phi_{e}}{2} \int_{0}^{L_{e}} \frac{1}{2}\left\{\sin \left(k_{e}+\mu_{j}\right) z-\sin \left(k_{e}-\mu_{j}\right) z\right\} d z \\
& \Phi_{a}=(-1)^{j} \Phi_{0}-\Phi_{1}
\end{aligned}
$$

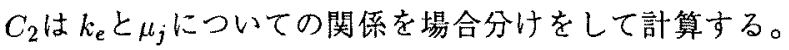


(a) $k_{e} \neq \mu_{j}$ のとき

$$
C_{2}=-\frac{\Phi_{e} \mu_{j}}{2\left(k_{e}^{2}-\mu_{j}^{2}\right)}\left(\cos \mu_{j} L_{e}+1\right)
$$

(b) $k_{e}=\mu_{j}$ のとき

$$
C_{2}=-\frac{\Phi_{e}}{8 \mu_{j}}\left(\cos 2 \mu_{j} L_{e}-1\right)=0
$$

(10)(13)(14) 式より、

$$
A_{0}=\left\{\begin{array}{lr}
\frac{\kappa^{2}}{\kappa^{2}-\mu_{j}^{2}} \Phi_{a}+\frac{k_{e}^{2}}{k_{e}^{2}-\mu_{j}^{2}} \frac{1+\cos \mu_{j} L_{e}}{2} \Phi_{e} \\
\frac{\kappa^{2}}{\kappa^{2}-\mu_{j}^{2}} \Phi_{a} & \left(k_{e} \neq \mu_{j}\right) \\
& \left(k_{e}=\mu_{j}\right)
\end{array}\right.
$$

とおくと、次式が成立する。

$$
F_{j}(R)=-\frac{2 A_{0}}{R L \mu_{j}}
$$

同様に $r=b$ の境界条件を積分すると、次式が成立する。

$$
F_{j}(b)=-\frac{1}{\beta} \frac{2 A_{0}}{R L \mu_{j}} \quad\left(\beta=\frac{b}{R}\right)
$$

$(15)(16)$ 式より $j \rightarrow i$ と置き換元れば、 $a_{J i} 、 a_{N i}$ は

$$
\left\{\begin{array}{l}
a_{J i}=\frac{2 A_{0}}{\beta R L \Omega_{i}}\left\{N_{1}\left(\nu_{i} R\right)-\beta N_{1}\left(\nu_{i} b\right)\right\} \\
a_{N i}=\frac{-2 A_{0}}{\beta R L \Omega_{i}}\left\{J_{1}\left(\nu_{i} R\right)-\beta J_{1}\left(\nu_{i} b\right)\right\}
\end{array}\right.
$$

と求められる。ただし

$$
\Omega_{i}=J_{1}\left(\nu_{i} R\right) N_{1}\left(\nu_{i} b\right)-J_{1}\left(\nu_{i} b\right) N_{1}\left(\nu_{i} R\right)
$$

これらの $a_{J i} 、 a_{N i}$ のもとで、 $\Phi$ は次のように計算される。

$$
\begin{aligned}
\Phi(r, z)= & \sum_{i} r F_{i}(r) \sin \mu_{i} z+\Phi_{1} \cos \kappa z \\
& +\left(\Phi_{0}-\Phi_{1} \cos \kappa L\right) \frac{\sin \kappa z}{\sin \kappa L}
\end{aligned}
$$

\section{これは求める解である。}

$\langle\mathbf{2} \cdot \mathbf{3}\rangle$ 規格化 以上求めた解析解中の変数に対して

$$
\rho=r / R, \quad \zeta=z / L, \quad \beta=b / R, \quad \alpha=L / R
$$

の規格化を行い、さらに以下のような変換を行い、規格量 で定義する。

$$
\begin{aligned}
& \mu_{i}^{\prime}=\mu_{i} L, \quad \nu_{i}^{\prime}=\nu_{i} R, \quad \kappa^{\prime}=\kappa L, \quad k_{e}^{\prime}=k_{e} L \\
& \varepsilon_{e}=L_{e} / L, \quad \varphi=\Phi / \Phi_{1}, \quad h_{0}=\Phi_{0} / \Phi_{1}
\end{aligned}
$$

ここで、 $\mu_{i}^{\prime}, \nu_{i}^{\prime}$ は次のと扔りである。

$$
\begin{cases}\mu_{i}^{\prime}=\pi i \quad(i=1,2,3, \cdots) \\ \nu_{i}^{\prime}=\frac{1}{\alpha} \sqrt{\kappa^{\prime 2}-\mu_{i}^{\prime 2}} \quad\left(\kappa^{\prime}>\mu_{i}^{\prime}\right) \\ \nu_{i}^{\prime}=\frac{1}{\alpha} \sqrt{\mu_{i}^{\prime 2}-\kappa^{\prime 2}} & \left(\mu_{i}^{\prime}>\kappa^{\prime}\right)\end{cases}
$$

$f_{i}, g_{i}, \Omega_{i}$ を

$$
\begin{aligned}
& f_{i}=J_{1}\left(\nu_{i}^{\prime}\right)-\beta J_{1}\left(\nu_{i}^{\prime} \beta\right), \quad g_{i}=N_{1}\left(\nu_{i}^{\prime}\right)-\beta N_{1}\left(\nu_{i}^{\prime} \beta\right) \\
& \Omega_{i}=J_{1}\left(\nu_{i}^{\prime}\right) N_{1}\left(\beta \nu_{i}^{\prime}\right)-J_{1}\left(\beta \nu_{i}^{\prime}\right) N_{1}\left(\nu_{i}^{\prime}\right)
\end{aligned}
$$

とおいて、さらに

$$
\begin{aligned}
A_{i} & =A_{0} / \Phi_{1} \\
& = \begin{cases}\frac{\kappa^{\prime 2}}{\kappa^{\prime 2}-\mu_{i}^{\prime 2}}\left\{(-1)^{i} h_{0}-1\right\} & \left(k_{e}^{\prime} \neq \mu_{i}^{\prime}\right) \\
+\frac{k_{e}^{\prime 2}}{k_{e}^{\prime 2}-\mu_{i}^{\prime 2}} \frac{1+\cos \mu_{i}^{\prime} \varepsilon_{e}}{2}\left(1-h_{0}\right) & \left(k_{e}^{\prime}=\mu_{i}^{\prime}\right) \\
\frac{\kappa^{\prime 2}}{\kappa^{\prime 2}-\mu_{i}^{\prime 2}}\left\{(-1)^{i} h_{0}-1\right\} & \end{cases}
\end{aligned}
$$

とすると、 $a_{J i}, a_{N i}$ は

$$
a_{J i}=\frac{2 A_{i} \Phi_{1}}{\beta R \mu_{i}^{\prime} \Omega_{i}} g_{i}, \quad a_{N i}=\frac{-2 A_{i} \Phi_{1}}{\beta R \mu_{i}^{\prime} \Omega_{i}} f_{i}
$$

となり、最終的にりは次のように計算できる。

$$
\begin{array}{r}
\varphi=\sum_{i} \frac{2 A_{i}}{\beta \mu_{i}^{\prime} \Omega_{i}} \rho\left\{g_{i} J_{1}\left(\nu_{i}^{\prime} \rho\right)-f_{i} N_{1}\left(\nu_{i}^{\prime} \rho\right)\right\} \sin \mu_{i}^{\prime} \zeta \\
+\cos \kappa^{\prime} \zeta+\left(h_{0}-\cos \kappa^{\prime}\right) \frac{\sin \kappa^{\prime} \zeta}{\sin \kappa^{\prime}}
\end{array}
$$

\section{3. 内側電極配位の平衡解析}

$\langle 3.1\rangle$ 内側電極配位モデル 次に、先の解析とは異な る電極配位を有する図 5のような内側電極配位のトーラス を模擬したモデルを考え、このモデルの平衡解を再び(2)式 を解くことにより導きだす。

先と同様に(2) 式を図5のモデルに関して一般解を求める と、次式のようになる。

$$
\Phi(r, z)=r\left\{a_{J} J_{1}(\nu r)+a_{N} N_{1}(\nu r)\right\} \cos \mu z+b_{0} \cos \kappa z
$$

ここで、 $a_{J}, a_{N}, \mu, b_{0}$ は定数であり、 $\nu$ は (4) 式と同様の値 である。またベッセル関数 $J_{1}, N_{1}, I_{1}, K_{1}$ に関する扱いは、 2 章と同様である。

図 5 の長さ $L_{e}$ の電極 (太線部分 $E_{+}, E_{-}$) 加ら外部電流 $I_{e}$ を流し込むとする。この場合の $\Phi$ に関する境界条件は電極 $E_{+}, E_{-}$の電源接続を図のように内側を通した場合、 $I_{z} に よ$ る磁界は内側のみに作用し、そこで $\Phi=\Phi_{0}$ となる。このと き境界条件は

$$
\begin{cases}\Phi=\Phi_{0} & (r=R \text { and }-k<z<k) \\ \Phi=\Phi_{1} & (z= \pm L / 2 \text { or } r=b)\end{cases}
$$
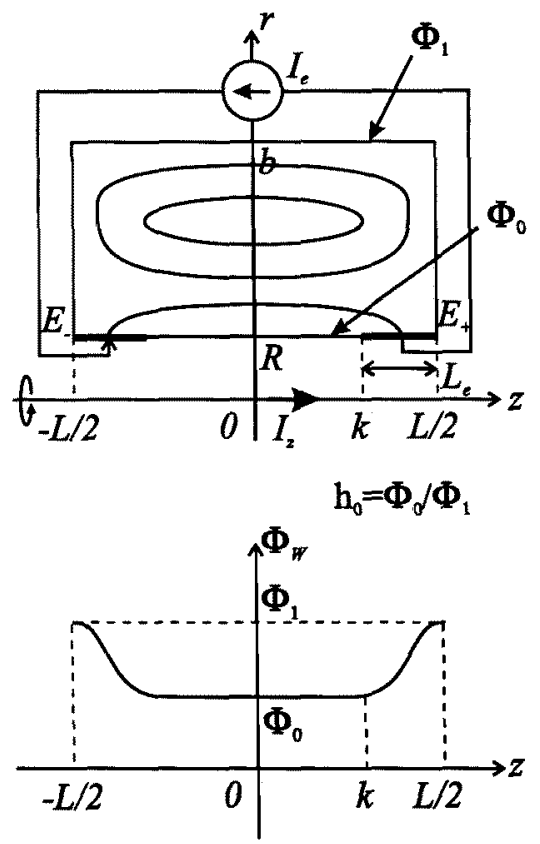

図 5 内側電極配位モデルと $r=R$ の境界条件。

Fig.5. Flux-core spheromak model and boundary condition at $r=R$. 
となり、電極部分は図5のように正弦波で近似する。した がって、 $r=R$ 境界上の $\Phi$ を $\Phi_{W}(z)$ とすると、(25) 式を考 慮すれば $\Phi_{W}(z)$ は次式のように求められる。

$$
\Phi_{W}(z)=\left\{\begin{array}{lr}
\frac{\Phi_{e}}{2}\left[\cos \left\{\frac{\pi}{L_{e}}(z-k)\right\}+1\right] & +\Phi_{1} \\
\Phi_{0} & (k<z \leq L / 2) \\
& (0 \leq z \leq k)
\end{array}\right.
$$

ただし、 $\Phi_{W}(z)$ は $r$ 軸に対して対称なので、 $z \geq 0 の$ 範囲で 考えることとする。 $z=L / 2$ の境界に注目すると、Фは $r$ に よらず一定なので (24) 式の右辺第 1 項は消えて、

$$
\left\{\begin{array}{l}
\cos \mu \frac{L}{2}=0 \rightarrow \mu=\mu_{i} \equiv \pi \frac{1+2 i}{L}(i=0,1,2, \cdots) \\
b_{0} \cos \kappa \frac{L}{2}=\Phi_{1} \rightarrow b_{0}=\frac{\Phi_{1}}{\cos (\kappa L / 2)}
\end{array}\right.
$$

これより、 $\mu$ は不連続值 $\mu_{i}$ をることがわかり、(24) 式の右 辺は各 $\mu_{i}$ の代数和となる。

$$
\rightarrow \Phi(r, z)=\sum_{i} r F_{i}(r) \cos \mu_{i} z+b_{0} \cos \kappa z
$$

ここで、 $\kappa=\mu_{i}$ とすると $b_{0}$ が発散するので、 $\kappa \neq \mu_{i}$ とする。

$\langle\mathbf{3} \cdot 2\rangle \quad a_{J i}, a_{N i}$ の計算 $\quad r=b, R$ Rおける境界条件

$\Phi(b, z)=\Phi_{1}, \quad \Phi(R, z)=\Phi_{W}(z)$

に(27) 式を代入し、それぞれの式の而辺に $\cos \mu_{j} z$ を忆 $z: 0 \rightarrow L / 2$ で積分して、2 章と同様の手法で $a_{J i}, a_{N i}$ を計 算すると、

$$
\left\{\begin{aligned}
a_{J i}= & \frac{1}{\Omega_{i}}\left[-\frac{A_{0} \Phi_{0}}{\beta}\left\{N_{1}\left(\nu_{i} R\right)-\beta N_{1}\left(\nu_{i} b\right)\right\}\right. \\
& \left.+B_{0} \Phi_{e} N_{1}\left(\nu_{i} b\right)\right] \\
a_{N i}= & \frac{1}{\Omega_{i}}\left[\frac{A_{0} \Phi_{0}}{\beta}\left\{J_{1}\left(\nu_{i} R\right)-\beta J_{1}\left(\nu_{i} b\right)\right\}\right. \\
& \left.-B_{0} \Phi_{e} J_{1}\left(\nu_{i} b\right)\right]
\end{aligned}\right.
$$

と求められる。ただし $\Omega_{i}$ は (17) 式で与えられ、 $A_{0}, B_{0}$ は次 式で与えられる。

$$
\begin{aligned}
A_{0}= & \frac{4}{R L \mu_{i}} \frac{\kappa^{2}}{\kappa^{2}-\mu_{i}^{2}}(-1)^{i} \\
B_{0} & = \begin{cases}\frac{2}{R L \mu_{i}} \frac{k_{e}^{2}\left\{(-1)^{i}+\sin \mu_{i} k\right\}}{\left(k_{e}^{2}-\mu_{i}^{2}\right)} & \left(k_{e} \neq \mu_{i}\right) \\
\frac{1}{R L \mu_{i}}\left\{2(-1)^{i}+2 \sin \mu_{i} k+\mu_{i} L_{e} \cos \mu_{i} k\right\} & \left(k_{e}=\mu_{i}\right)\end{cases}
\end{aligned}
$$

これらの $a_{J i} 、 a_{N i}$ のもとで、Фは次のように計算される。

$$
\Phi(r, z)=\sum_{i} r F_{i}(r) \cos \mu_{i} z+\Phi_{1} \frac{\cos \kappa z}{\cos (\kappa L / 2)}
$$

$\langle 3 \cdot 3\rangle$ 規格化 同軸電極配位モデルと同様に、このモ デルも規格化された量で表す。(19)(20) 式と同様に各定数 を定義し、 $\varepsilon_{e}$ のみ $\varepsilon_{e}=2 L_{e} / L$ と置き換える。ここで、能は

$$
\mu_{i}^{\prime}=\pi(1+2 i) \quad(i=0,1,2, \cdots)
$$

と書け、 $\nu_{i}^{\prime} は(21)$ 式と同様に書ける。(22) 式のように $f_{i}, g_{i}$, $\Omega_{i}$ をおて、さらに

$$
\begin{aligned}
& A_{i}=R A_{0}=\frac{4}{\beta \mu_{i}^{\prime}} \frac{\kappa^{\prime 2}}{\kappa^{\prime 2}-\mu_{i}^{\prime 2}}(-1)^{i} \\
& B_{i}=R B_{0}=
\end{aligned}
$$

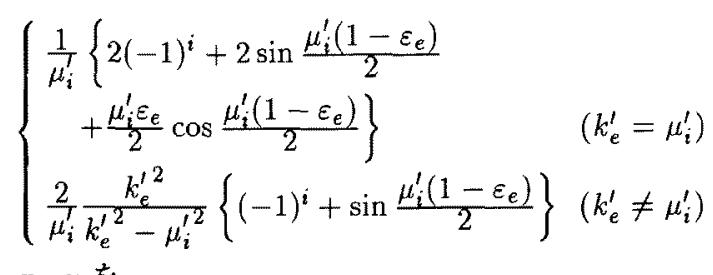

とし、 $x_{i}, y_{i}$ を

$$
\left\{\begin{array}{l}
x_{i}=\frac{R a_{J_{i}}}{\Phi_{0}}=\frac{-1}{\Omega_{i}}\left\{A_{i} g_{i}-B_{i} N_{1}\left(\nu_{i}^{\prime} \beta\right)\left(h_{1}-1\right)\right\} \\
y_{i}=\frac{R a_{N i}}{\Phi_{0}}=\frac{1}{\Omega_{i}}\left\{A_{i} f_{i}-B_{i} J_{1}\left(\nu_{i}^{\prime} \beta\right)\left(h_{1}-1\right)\right\}
\end{array}\right.
$$

と定義すると、 $\varphi$ は次のように計算できる。

$$
\varphi=\sum_{i} \rho\left\{x_{i} J_{1}\left(\nu_{i}^{\prime} \rho\right)+y_{i} N_{1}\left(\nu_{i}^{\prime} \rho\right)\right\} \cos \mu_{i}^{\prime} \zeta+\frac{\cos \kappa^{\prime} \zeta}{\cos \left(\kappa^{\prime} / 2\right)}(29)
$$

\section{4. 計算結果および考察}

〈4.1〉磁気面と安全係数の計算法 以上 2 章と 3 章で 述べた $2 つ の$ 電極配位に関して、磁気面と安全係数 $q$ の分 布の計算を行った。計算に際しては両モデルとも規格化し た後の式を用い、トーラス断面 (矩形) 内での規格化磁気面 ( $\varphi=$ 一定の面) を計算した。 $\varphi$ の計算式に現れる展開の次数 iについては、 $i=n$ までの和をとった $\varphi$ を $\varphi_{n}$ とたときに

$\varphi_{n}-\varphi_{n-1}<0.01$

となる範囲まで計算した。アスペクト比

$$
A=\frac{(R-b) / 2+2}{(R-b) / 2}=\frac{1+\beta}{1-\beta}
$$

は低アスペクト比領域 $(A=1.1)$ とし、楠円度 $(e l=L /(R-$ $b)=\alpha /(1-\beta))$ は $2.0 、 \varepsilon_{e}=0.2$ と設定した。また $q$ 值は磁 気面Фを用いて

$$
q=\frac{1}{2 \pi} \frac{d \Phi_{\varphi}}{d \Phi} \quad\left(\Phi_{\varphi}: \text { トロイダル磁束 }\right)
$$

と定義し、これを規格化条件にあてはめて計算した。

$\langle 4 \cdot 2\rangle$ 計算結果 磁気面と $q$ 分布に対する $h_{0}$ と $\kappa^{\prime}$ の影 響を大まかにつかむため、それぞれの電極配位に対して、

$$
h_{0}=0.0,0.5,1.0,2.0, \quad \kappa^{\prime}=3.5,4.5,5.5,6.5
$$

としたときの計算を行った。

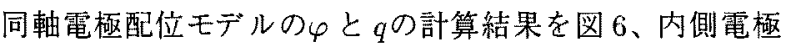
配位モデルの計算結果を図7に示す。ただしりは等高線で表 示し、図の太線はプラズマの境界(セパラトリックス)、害 線はプラズマの内部、破線は真空領域を表している。また 後の考察のため、それぞれのモデルに関して $\kappa^{\prime} 4.5$ に固定 して、 $h_{0}$ を 0.5, 0.6, 0.7,0.8としたときのq分布の計算結果 を図8に示す。 $q$ 值はプラズマ内部 (図の太線内部) のみにお いて (30) 式を用いて計算した。グラフの横軸 $\varphi_{\mathrm{c}}$ はプラズマ 内部の $\varphi$ を規格化した值を表し、 $\varphi_{c}=0$ は磁気軸、 $\varphi_{c}=1$ はセパラトリックスをそれぞれ表す。ここで図 6(a) に関し ては、Кが 3.5 6.5 の範囲ではプラズマ領域が生成されな いため、Кの範囲を7.0〜7.6とした。また $q$ 值については、 通常磁気軸が1つの場合について議論されているので、図

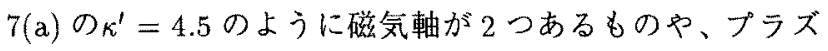
マ領域が存在しないものについては考慮しない。

Кの值をこれらの計算よりもさらに大きくしていくと、あ る值的で $\varphi$ の值が無限大に発散する特異点が存在する。例 

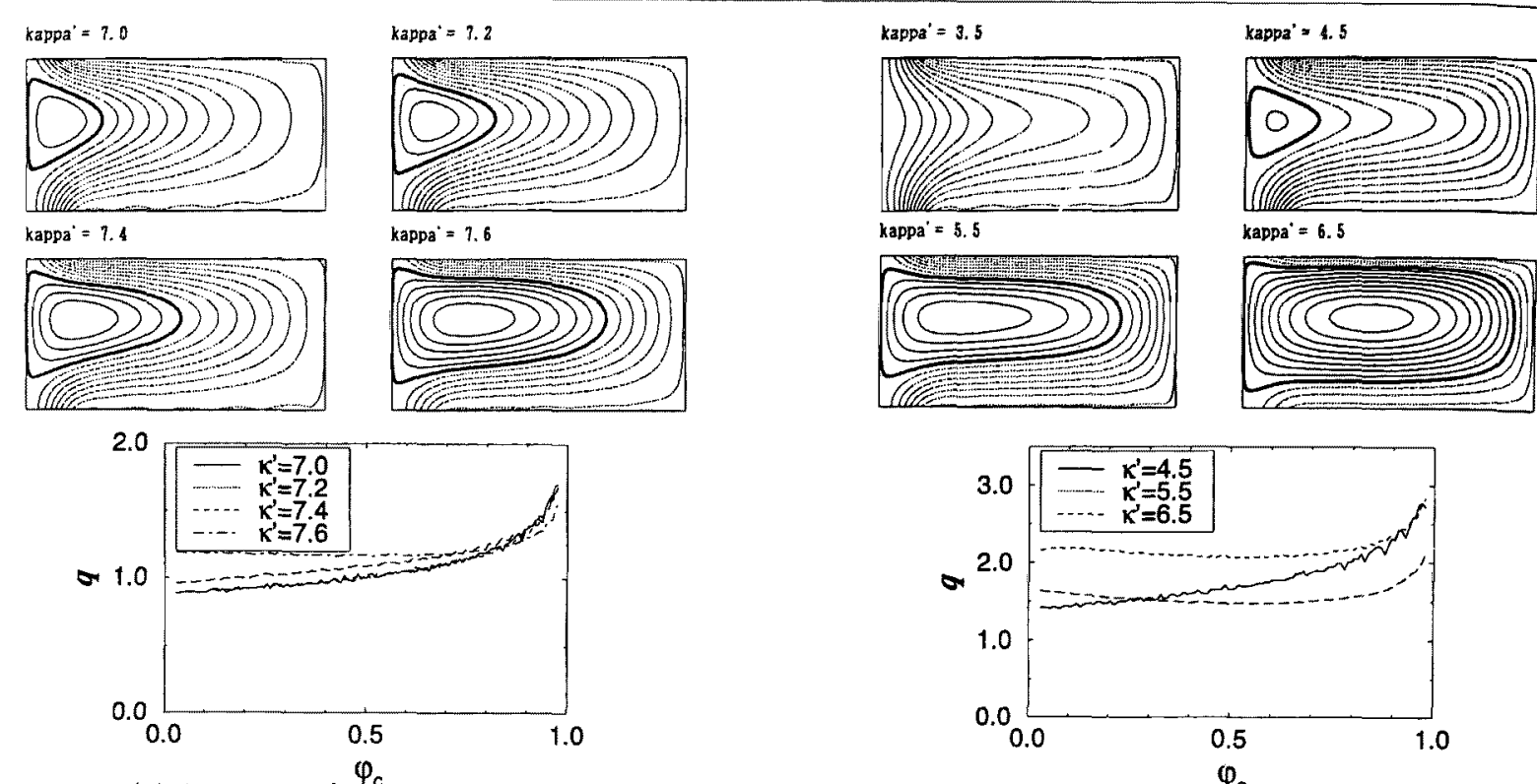

(a) $h_{0}=0.0, \kappa^{\prime} \stackrel{\varphi_{c}}{=} 7.0 \sim 7.6$

(b) $h_{0}=0.5, \kappa^{\prime} \stackrel{\varphi_{c_{c}}}{=} 3.5 \sim 6.5$
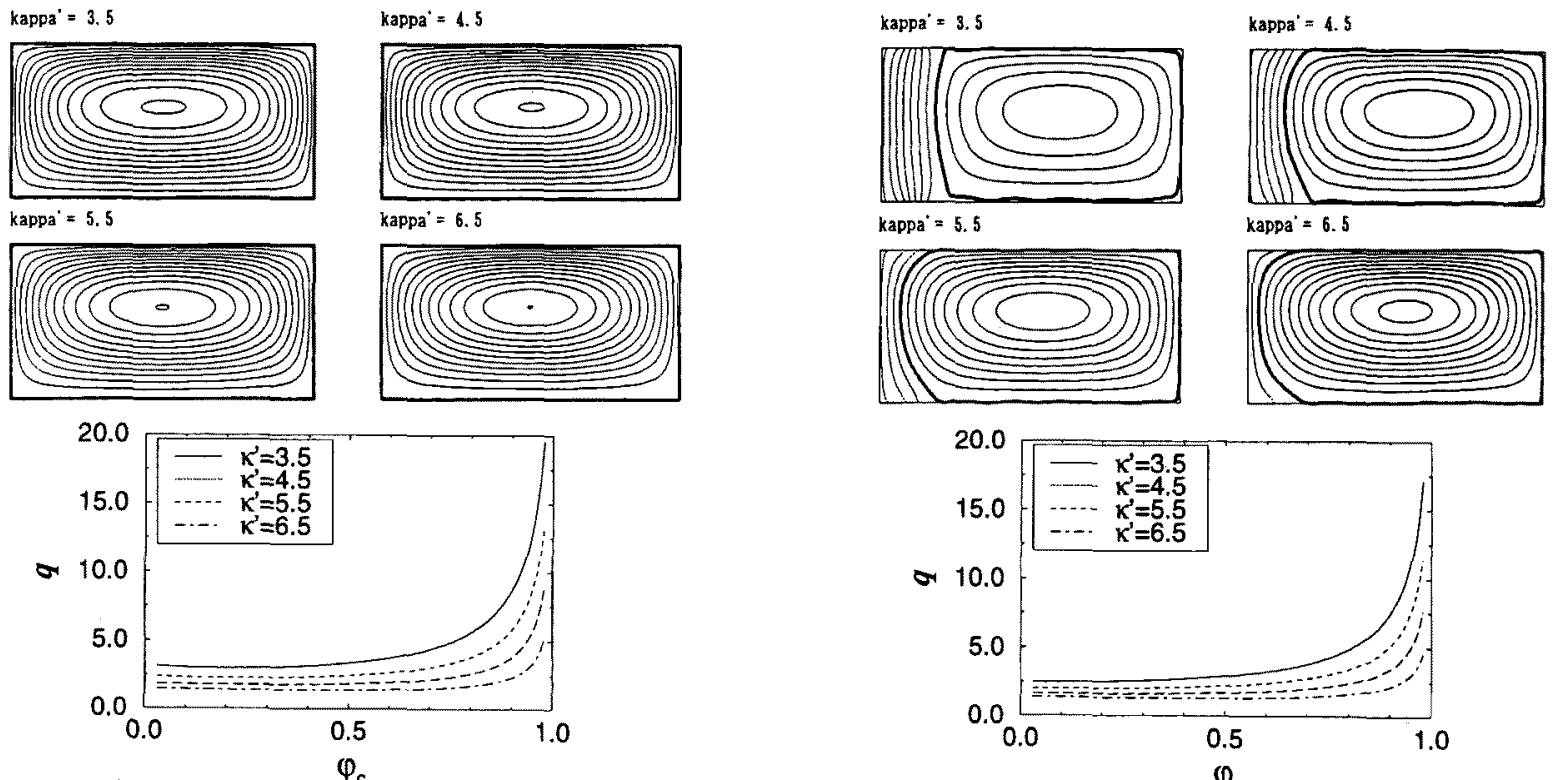

(c) $h_{0}=1.0, \kappa^{\prime} \stackrel{\varphi_{c}}{=} 3.5 \sim 6.5$

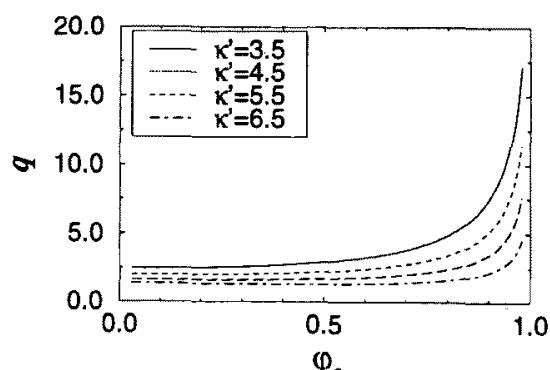

(d) $h_{0}=2.0, \kappa^{\prime} \stackrel{\varphi_{c}}{=} 3.5 \sim 6.5$

図 6 同軸電極配位モデルの $\varphi$ の平衡解と $q$ 分布。

Fig.6. Contours of $\varphi$ and safety factor $q$ profile of HIT model with different $h_{0}$ and $\kappa^{\prime}$.

えば $h_{0}=0.0$ では $\kappa_{0}^{\prime} \sim 8.0$ である。さらに $\kappa^{\prime}>\kappa_{0}^{\prime}$ では磁 気軸が 2 つできる 2 分化された配位が現れるが、今回の計 算では実験上興味の対象となる

$\langle 4 \cdot 3\rangle \quad h_{0}$ および物理的意味 ここでは $h_{0}$ および Кの物理的意味を説明して、これらの定数が磁気面配位と $q$ 分布に与える影響を考察する。図40同軸電極配位モデ ルを例にとると、 $\Phi \propto B_{\varphi} / r$ であることを考虑に入れれば 境界条件 $\Phi_{0}$ と $\Phi_{1}$ の関係は次のように考えられる。まず中心 電流 $I_{z}$ によりトロイダル磁界 $B_{\varphi}$ が発生し、境界上の磁気 面が $\Phi=\Phi_{0}$ となる。さらに図 4 の例のような向きに外部電

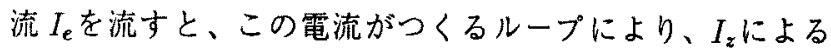
$B_{\varphi}$ と同じ向きに $B_{\varphi}$ が生じる。したがって $z=0$ 上の $B_{\varphi}$ はさらに強くなり、境界条件は $\Phi_{1}>\Phi_{0}$ となる。これはす
なわち $0.0<h_{0}<1.0$ の場合に相当する。同様の考察に より、 $h_{0}>1.0$ のときは $I_{\mathrm{e}}$ の向きが図 4 の向きと逆の場合 であることがわかる。また $I_{z}=0$ のときには $\Phi_{0}=0$ より $h_{0}=0.0 、 I_{e}=0$ のときには $\Phi_{1}=\Phi_{0}$ となり $h_{0}=1.0$ であ ることがわかる。図5の内側電極配位モデルについても同 様の考察ができ、以上まとめると次の上うな結論が得られ る。 $h_{0}=0.0$ は外部トロイダル磁界が存在しないスフェロ マック形、 $h_{0}=0.5$ は図 4、図 5 の電流の向きに電流が流れ る配位 (外部卜ロイダル磁界と流入電流によるトロイダル 磁界が互いに和し合う方向)、 $h_{0}=1.0$ はへリシティー注入 のないトカマク配位、 $h_{0}=2.0$ は図 4 、図 5 と、電極電流の 向きが逆となっている配位である。

一方 $\kappa^{\prime}$ (1)(20) 式で定義されているように、 $\varphi$ から $B_{\varphi}$ 


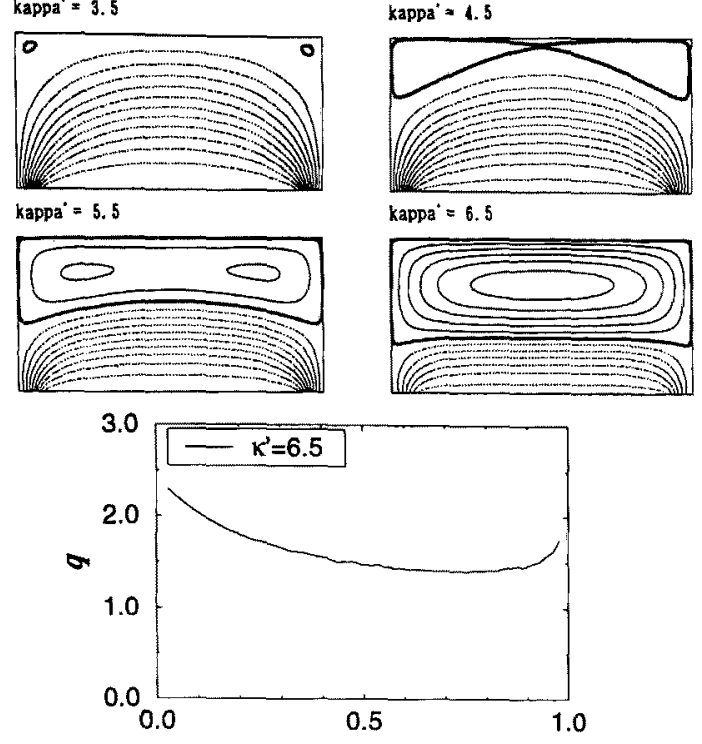

(a) $h_{0}=0.0, \kappa^{\prime} \stackrel{\varphi_{c}}{=} 3.5 \sim 6.5$

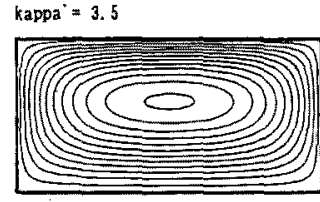

kappa' $=5.5$
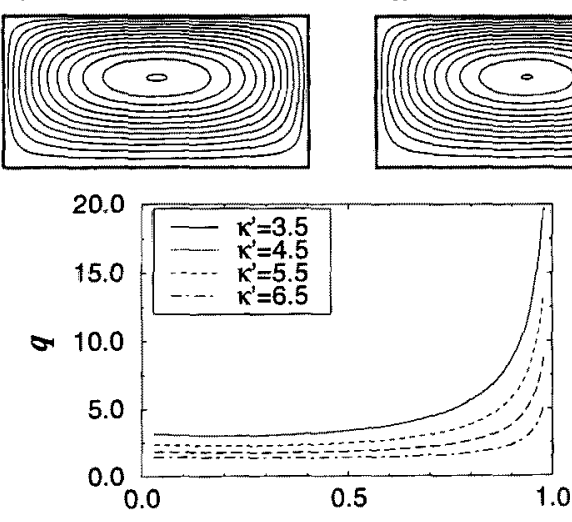

(c) $h_{0}=1.0, \kappa^{\prime} \stackrel{\varphi_{c}}{=} 3.5 \sim 6.5$

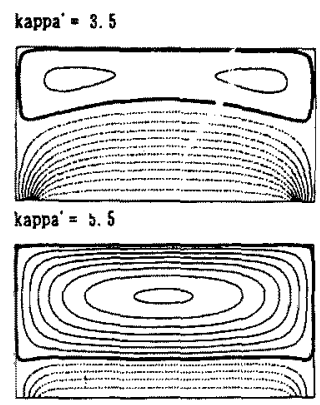

kappa $=4.5$

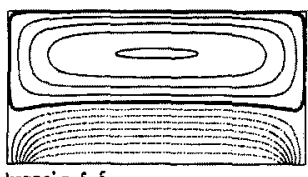

$\mathrm{kappa}^{\circ}=6.5$
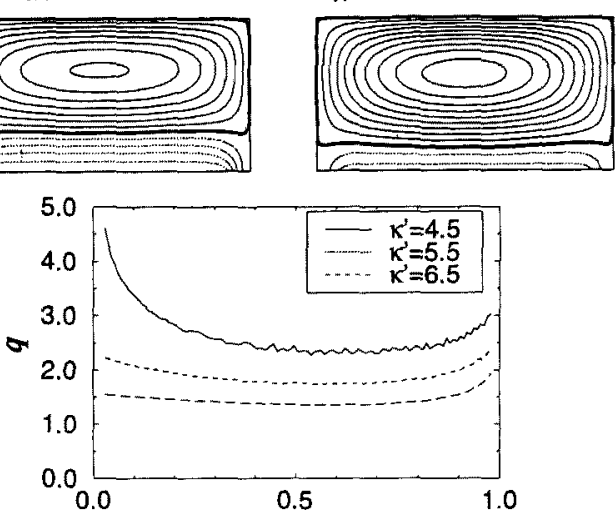

(b) $h_{0}=0.5, \kappa^{\prime} \stackrel{\varphi_{c}}{=} 3.5 \sim 6.5$
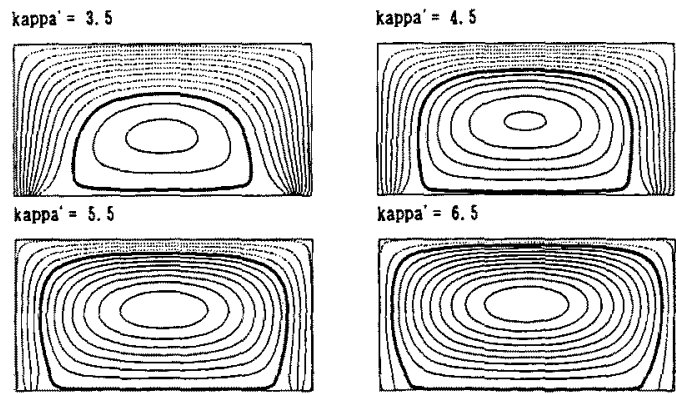

kappa $=6.5$
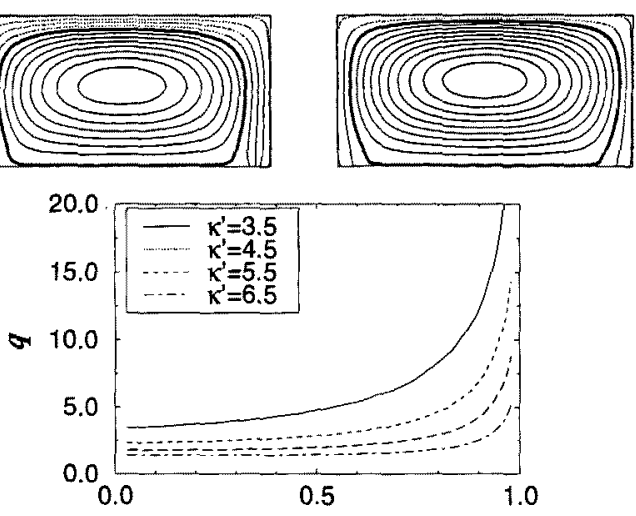

(d) $h_{0}=2.0, \kappa^{\prime} \stackrel{\varphi_{c}}{=} 3.5 \sim 6.5$

図 7 内側電極配位モデルの $\varphi$ の平衡解と $q$ 分布。

Fig.7. Contours of $\varphi$ and safety factor $q$ profile of flux-core spheromak model with different $h_{0}$ and $\kappa^{\prime}$.

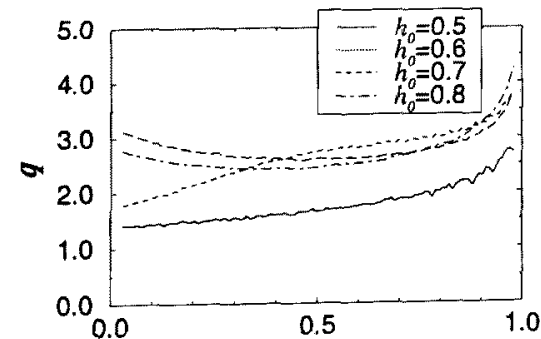

(a) 同軸電極配位モデ)

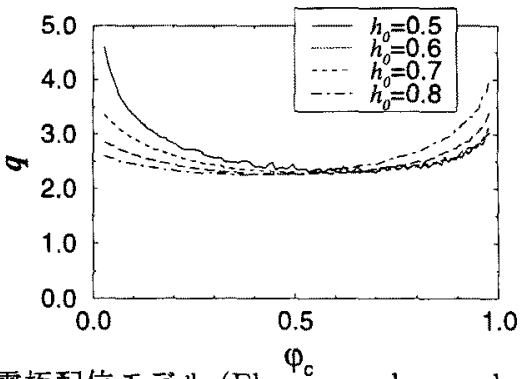

(b) 内側電極配位モデル (Fluxcore spheromak model)

図 8 負の傾きをもつq分布 $\left(\kappa^{\prime}=4.5,0.5 \leq h_{0} \leq 0.8\right)$ 。

Fig.8. Safety factor $q$ profiles with negative shear $\left(\kappa^{\prime}=4.5,0.5 \leq h_{0} \leq 0.8\right)$. 
を計算する際の比例定数である。したがって同じ境界条件 の場合、 $\kappa^{\prime}$ が大きくなるとそれに比例して境界上での $B_{\varphi}$ が 大きくなる。すなわち $I_{z}$ 抢よび $I_{e}$ が大きくなることを意味 する。またんは $\operatorname{rot} \boldsymbol{B}=\kappa \boldsymbol{B} \propto \boldsymbol{j}$ とも定義され、プラズマ電 流密度は $j_{\varphi} \propto B_{\mathrm{pol}}$ と $B_{\mathrm{pol}}$ に比例するので、 $B_{\varphi}$ とポロイダ 儿磁界 $B_{\mathrm{pol}}$ の比例定数でもある。 $\kappa^{\prime}$ が大きいと $B_{\mathrm{pol}}$ の割合 が、ผが小さいと $B_{\varphi}$ の割合が大きくなり、前者の場合、こ れはプラズマ電流が大きいことを意味する。この傾向は、 図 6,7の磁気面の計算結果によく現れている。また後者の 場合、これは $q$ 值が大きくなることを意味し、同じく図 6,7 の $q$ 分布の計算結果に傾向が現れている。以上より、长を大 きくするとプラズマ電流を大きくできるが、プラズマ電流 維持のための $I_{z}, I_{e}$ も大きくなり、q值が小さくなり不安定 になる、と結論づけられる。

$\langle 4.4\rangle$ 安全係数 $q$ に関する考察 安全係数 $q$ 値は、ス フェロマックでは磁気軸からセパラトリックスにむけて減 少していき、へリシティー注入のない通常卜カマクでは逆 に増加していく傾向があるが、図 6,7 の $h_{0}=0.0$ の $q$ 分布 を見ると、必ずしもスフェロマックの傾向は現れていない。 同軸電極型ではプラズマ領域が生成された時点ですでに $\kappa^{\prime}$ の值が大きく、qの值が小さすぎること、内側電極型では $\kappa^{\prime}$ が小さい值ではプラズマ領域に磁気軸が 2 つ現れており、q 分布が極大值をもつような特異な配位になっていることが その理由であると考えられる。一方 $h_{0}=1.0$ の q分布には、 通常卜カマクの特徴が現れている。また、 $h_{0}=2.0$ とした ときの $q$ 分布は $h_{0}=1.0$ の場合と大きな違いはなく、へリシ ティー注入による閉じ込め特性の大きな改善は見られない。

$q$ 分布に関して注目すべき結果が得られているのは、 $h_{0} か ゙$ $0 \sim 1$ の間、例えば $h_{0}=0.5$ のときである。この q分布にはス フェロマックとトカマクの両者の特徴が現れており、中には $q$ 分布が極小值をもち、中心付近で磁気シアー $(s=d q / d r)$ が負になり、周辺で $s>0$ となるようなものも存在してい る。このような凹状の $q$ 分布は負磁気シアー配位と呼ばれ、 トカマクで閉じ込め特性が改善されるものとして近年注目 されている(10)。そこで、この負磁気シアー配位について検 討してみる。 $\kappa^{\prime}$ を 4.5 に固定し、 $h_{0}=0.5 \sim 0.8$ としたとき の両モデルの q分布を图 8 に示す。ここで $\kappa^{\prime}$ は、磁気軸での $q$ 值 $q_{0}$ と周辺部での $q$ 值 $q_{a}$ が、ともに 3 を越える程度の值 として 4.5 とした。まず図 8(b) から見てみると、 $h_{0}$ が増加 するにつれてq分布がスフェロマック型からトカマク型に 移行し、その過程で負磁気シアー配位が達成されているこ とがわかる。図 8(a) では $h_{0}=0.5,0.6$ ではスフェロマック 型から大きく外れているが、これは図 6(b) からわかるよう にプラズマ領域が極端に小さく、典型的な閉じ込め配位が 形成されていないためであると考えられる。しかし一方、 $h_{0}=0.7,0.8$ では負磁気シアー配位が形成されている。

以上の議論より、 $0.0<h_{0}<1.0$ では $h_{0}$ が増加すると $q$ 分 布がスフェロマック型からトカマク型へ移行し、この間で

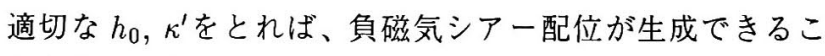
とがわかった。

\section{5. 結言}

本論文に扔いて、電極を通して外部電流を注入するへリ シティー注入型の低アスペクト比トカマクの解析解を求め た。特に負のシアーをもつ逆転 $q$ 分布が条件によって達成さ れ、その場合閉じ込め改善の期待が持てる。また、これら 解析解は今後、同配位の動作を数值シミュレーションする 場合の初期条件として有用であろう。また、最近同軸電極 配位に加えて内側電極配位の実験が日米でそれぞれ開始さ れたため(12)、実験との対比に興味が持たれる。

最後に、本研究を遂行するにあたり、森田歩氏(現日立製 作所) の協力に感謝する。

(平成 8 年 7 月 17 日受付、平成 8 年 12 月 16 日再受付)

\section{文 献}

(1) 小野 亮·森田·小野 靖·桂井: 電気学会論文誌 A, 116, 128 (1996)

(2) 山田: プラズマ・核融合学会誌, 72, 205 (1996)

(3) 例えばJ. B. Taylor: Review of Modern Phys., 58, 741(3) (1986), および T. Jaboe: Plasma Phys. Control Fusion, 36, §6.1 (1994)

(4) J. B. Taylor: プラズマ物理・核融合第 5 回 IAEA 会議録 IAEACN-33/PD-1, 161 (1975), およびB. B. カドムツェフ (難波、水野 訳):「プラズマ中の集団現象」，岩波書店, §3.5, §5.6 (1978)

(5) L. Woltjer: Proc. National Academy of Science, 44, 489 (1958)

(6) J. B. Taylor and M. F. Turner: Nucl. Fusion, 29, 219 (1989)

(7) T. H. Jensen and M. S. Chu: J. Plasma Phys., 25, 219 (1981)

(8) N. Amemiya, A. Hayakawa and M. Katsurai: J. Phys. Soc. Jpn., 60, 2632，(1991)，およびN. Amemiya, et al.: J. Phys. Soc. Jpn., 62, 1552 (1993)

(9) T. Jarboe et al: プラズマ物理・核融合第 15 回 IAEA 会議録 IAEACN-60/II-6-1 (1994)

(10) E. J. Strait, et al.: Phys. Rev. Lett., 75, 4421 (1995), および C. Kessel, et al.: ibid., 72, 1212 (1994)

(11) 桂井他: プラズマ・核融合学会誌, 64, 362 (1990)

(12) 遠山、および英国カラム研究所 STARTグループ: 1996 年国際コ ンパクトトカマクおよび日米低アスペクト比トカマクワークショッ プ,カラム研究所 (英国), 12 月, 1996

小野亮 (学生員) 1973 年 3 月 26 日生。1995 年 3 月

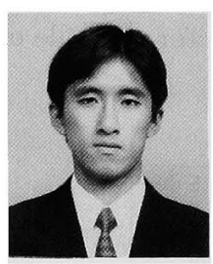
東京大学工学部電気工学科卒業。同年 4 月同 大学大学院工学系研究科電気工学専攻修士課 程進学。計算機シミュレーションによる、ト カマクの平衡解析の研究に従事。

桂井誠 (正員) 1941 年 11 月 13 日生。1965 年東京大

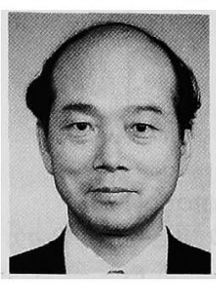
学工学部電子科卒業。1970 年同大学大学院博 士課程修了。同年同大学講師、1971 年同助教 授、1987 年教授、現在に至る。工学博士。こ の間 1978 年 10 月 80 年 1 月アメリカ・プリ ンストン大学プラズマ物理研究所に滞在。主 として、プラズマ工学、核融合工学の研究に 従事。プラズマ・核融合学会、IEEE 会員。 